\title{
Preventive Approach to Unsubstantiated Claims and Disputes in the UK Construction Industry
}

\author{
Asia Nosheen \\ nosheen2@uni.coventry.ac.uk \\ Coventry University, Coventry, UK \\ Andrew Oyen Arewa \\ andrew.arewa@coventry.ac.uk \\ Coventry University, Coventry, UK \\ Hafiz Muhammad Akhtar \\ engakhtar@hotmail.com \\ M/s Progressive International (Engineers \& Contractors), Lahore, Pakistan
}

\begin{abstract}
Globally, claims and disputes are an unfortunate reality in construction projects. Recent statistics reveal that construction claims in the UK increased by $21 \%$ in 2018 compared to other countries such as India (8\%), Mexico (3\%), Ireland (2\%), and Cyprus (2\%). Though, construction industry is known for array of standard forms of contract and administrative tendencies; unsubstantiated claims and chronic disputes remain prevalent in the sector. Yet, there is little research on preventive approach to unsubstantiated claims that ultimately lead to disputes. The study advocates the use of Systematic and Technical Appraisal (STA) to prevent unsubstantiated claims and disputes in the construction industry. The study research method is based on qualitative research technique and use of case studies. The research question is: does systematic and technical appraisal of construction claims help prevent unsubstantiated claims and disputes in the UK construction industry? The study population sample is drawn from experienced industry stakeholders including clients, contractors, consultants, experienced quantity surveyors and cost managers in addition to use of construction case studies. Initial findings reveal that claim management processes in the construction sector are far-off from perfection. Other findings reveal that robust systematic and technical claim appraisal process has potential to prevent unsubstantiated claims; which in most cases lead to disputes. The study is part of an on-going PhD study to seek to develop an effective claim management system for the UK construction industry.
\end{abstract}

Keywords: Claims; Dispute; Systematic and technical claim appraisal

\section{INTRODUCTION}

In the last two decades, incomplete and unsubstantiated construction claims consistently featured as the second most common reasons for chronic unfair claim issues and disputes in the construction industry. Average value of construction disputes across the globe currently stands at approximately US $\$ 43.4$ million; with average length of disputes spanning over 14.8 months (ARCADIS, 2018). For example, ARCADIS (2018) report stated that the highest value of construction claim and dispute handled by their team in 2017 was worth of US\$400M, and the root causes stem from unsubstantiated 
claims. Recent statistics reveal that construction claims in the UK increased by $21 \%$ in 2018 compared to other countries such as India (8\%), Mexico (3\%), Ireland (2\%), and Cyprus (2\%) (LCIA, 2018). Indeed, unsubstantiated claims in construction businesses are complex issues and often difficult research subject area perhaps, due to unrealistic assumption of claimants, nature of work, dubious rate, inexperience of claim administrator, etcetera. Yet, there is little research on strategic and preventive approach to unsubstantiated claims that ultimately lead to chronic disputes. Therefore, the study seeks to advance knowledge on how to strategically deal with unsubstantiated claims and disputes in the UK construction industry. For better understanding of the research theme; there is need for robust literature review.

\section{LITERATURE REVIEW}

Construction claims for loss/expenses, extension of time (EoT) and liquidated damages (LD) are important aspect of contract administration; because of its monetary value. A single claim in construction can vary significantly in value usually as low as $£ 250$; spanning hundreds and millions of pounds ( $£$ ) in a single project (LCIA, 2018). Arguably, value of construction claims in a project depends on complexity, alterations and variations to original contract. Claims are common occurrences to both small and large projects. Tochaiwat and Chovichien (2004) argued that claim is simply a process that involves seeking for consideration or changes to an arrangement by contractual parties. Generically, claim is simply a mechanism that allows contracting parties to seek for recompense or compensation such as loss/expenses, EoT and LD if a contractor delays the project. In construction business, claims are often caused by arrays of factors such as variation, instruction, unforeseen circumstances, action or indecisiveness of client's representative. Moreover, claims in construction can also arise from external event such as adverse weather conditions and force majeure. Bonaventura (2015) asserted that "when a party believes that the other party has not met the contractual obligations or expectations and that they deserve monetary and/or time compensation, they may submit a claim". Most literature hardly explains unsubstantiated claims and strategic approach to prevent ambiguous contractor's claims. Unsubstantiated claims are vague, abstruse, unsupported with evidence. Professionally, claims are deemed to be invalid or incorrect and should not be processed. Long (2017) stressed that most cases of unsubstantiated claims usually come from construction contractors; and they are leading causes of construction disputes. Arcadis (2018) opined that disputes in construction can only be brought to bare minimum if claims are clearly substantiated and corroborated with sufficient evidence.

\subsection{Potential of making unsubstantiated claims valid}

The National Economic Development Office (NEDO, 2011) asserted that 60\% construction claims are as a result of delays due to groundwork, in a study that involves 5,000 industrial buildings, 8,000 commercial buildings, 200 roads and bridges. Navigant Construction Forum (2012) stated that for fast approval and payment of claims; claimants need to support their claims with proof that are beyond reasonable doubt. Moreover, use of modern technologies and applications such as expensive smart receipts, applied epic, claim center, snap sheet and office lens, claims can be easily managed and supported 
with robust evidence. However, it could be argued that these technologies are hardly used in processing construction claims for various reasons such slow adaption of emerging technologies; lack of awareness, technical expertise, and traditional nature of the industry. In addition, emerging technologies do exist; claim administrators do often not accept them for reasons aligned to lack of awareness.

\subsection{Importance of substantiated claims in construction}

Hameed et al. (2014) asserted that unsubstantiated claims often lead to multifaceted problems in construction such as; (i) creates cash flow difficulties for contactor, (ii) delayed project (iii) disputes (iv) unnecessary administrative costs, etc. From contract perspective, unsubstantiated claim has potential to foil corrupt activities and breaches to a contract. Conversely, claims are significant to construction contract management to promote fairness, transparency and smooth running of construction project. Claim also act as back up to insurance arrangement and enhances confidence in entire contractual processes. More importantly substantiated claims help avert prolong or delay payment or extension of time (EoT); a deep-rooted problem that cut across hierarchies of construction supply chain.

\subsection{Factors that influence contractual claims in construction}

Claims happen in numerous forms and shape ranging from discrete to relational arrangement. However, there is barely any contract that guarantees non-occurrence of claims and disputes; particularly as it relates to construction projects. However, there is need to understand factors that influence construction claims from a broad point of view. Table 1 below illustrates factors that influence construction claims in different stages of construction circle.

Table 1: Construction stages and likely factors that influence claims

\begin{tabular}{|c|c|c|}
\hline \multicolumn{2}{|r|}{ Construction stages } & Key factors that influence claims \\
\hline 1. & Project conception & $\begin{array}{l}\text { - Unrealistic assumptions in tendering and contracting stage } \\
\text { - } \quad \text { Incompleteness of basic engineering package }\end{array}$ \\
\hline 2. & Construction & $\begin{array}{ll} & \text { Unfair contractual clauses } \\
\text { - } & \text { Ambiguity in contracts } \\
\text { - } & \text { Detail contracting vs. non contractual factors } \\
\text { - } & \text { Relational contracts (Risk) } \\
\text { - } \quad \text { Variation } & \text { Instructions from PM or contract administrator etc. } \\
\end{array}$ \\
\hline 3. & Post construction & $\begin{array}{ll} & \text { Claim as contractor's right } \\
\text { - } & \text { Problems with payment of retention } \\
\text { - } \quad \text { Compromising over claims } \\
\text { - } \quad \text { Personalities } \\
\text { Final account claims }\end{array}$ \\
\hline
\end{tabular}

Moreover, World Bank Report (2012) suggested that on a global scale claim management is somewhat influenced by host of factors; particularly in countries known for excellent contract enforceability. Table 2 illustrates (World Bank, 2012) ranking of countries with contract enforceability. The ranking started from number 1 to 257 (denoting 1 as excellent and higher figure as worst along the scale). Factors considered in the (World Bank, 2012) ranking include effective claim management system, ease of 
doing business, friendliness to entrepreneurs, openness, fair justice system etc. Similarly, the International Bank for Reconstruction and Development argued that countries with poor contract enforceability ranking are more likely to have checkered history of unsubstantiated claims.

Table 2: World Bank (2012) ranking of countries with contract enforceability

\begin{tabular}{|c|c|}
\hline Country & Enforcing Contracts \\
\hline Luxemburg & 1 \\
\hline Germany & 6 \\
\hline France & 7 \\
\hline United Kingdom & 21 \\
\hline Sweden & 54 \\
\hline Spain & 54 \\
\hline Greece & 91 \\
\hline Qatar & 95 \\
\hline Brazil & 118 \\
\hline Pakistan & 154 \\
\hline Italy & 158 \\
\hline Angola & 181 \\
\hline India & 182 \\
\hline
\end{tabular}

\subsection{Overview of construction claims and disputes in the UK}

Russel (2001) asserted that in the UKthe second and fourth most recurrent matter of litigation between main contractors and employers relate to contractor's claims of extension of time (EoT) and loss and expenses (L\&E). This assertion is the same for other countries such as Canada, Australia and USA (Hartman, 1994); (Uher, 1994) and (Paulson, 1992). Wong (2005) stated that disputed construction issues in Singapore are contractor's claims for variation and project delays. Kumaraswamy (2003) stressed that construction claims are usually muddled up by inexperience claim administrators; "fundamental mess while dealing with claims is the existence of conflict of interest between the employer, contractor and claim certifier".

Indeed, "construction claims can be based on nature of contract itself, common law and quasi-contractual assertion for reasonable (quantum meruit) competition or an ex-gratia settlement request (Kumaraswamy, 2003). Array of court cases relating to construction shows that claim is closely related to dispute; thus, Yates (2003) suggested that claims are resolved problems without turning into disputes.

Vidogah and Ndekugri (1998) are of the view that effective claim management requires a lot of resources like responsible personnel, good documentation and record keeping. For example, project correspondence, amended drawings, specifications, request for information (RFI), cost breakdown and measurement records need to be well documented. Kumaraswamy (2003) opined that claims if managed appropriately can lead to potential improvement to work designs due to cross exchange of ideas between parties. Practically, claims are easy to create but substantiation is often complex 
(Chappell, 2014).

Review of literature shows that effective claim management requires detailed attention to avoid potential contractual disputes. This can only be achieved through proper recording of documents and provision of knowledgeable personnel.

Indeed, claims can be problematic to both clients and contractors if they are not dealt in a timely manner. Outcome of claim can be either a settlement or a potential dispute. Purpose of claim management process in construction industry is to acquire certain solution to minimize the impact of claim on project delivery. Vidogah and Ndekugri (1998) stated that claim management is not often recognized as management function due to lack of investment of technical expertise. However, effective claim management can be profitable to a contractor if managed appropriately.

\subsection{Effectiveness claim management in construction}

The key objective of the claim management process is to resolve claims made by a contractual party in an effective and efficient manner in order to avoid costly, lengthy disputes and to maintain cordial relationship. Arguably, most claims in construction are not taken seriously at project level; thus, it is often associated with disputes. Sun and Meng (2009) observed differences in terminologies used to describe effective claim management in past literature; some authors believe that effective claim management is all about predicted claims, as claims, good change orders or vice versa (Levin, 1998). Thus, all relevant terms, which need clarification with respect to claim management, are discussed. However, Sun and Meng (2009) suggested that effective claim management must entail:

- Speedy decision from the authorized claim administrator;

- Cost saving;

- Fairness;

- Substantiated costs;

- Win-win attributes.

\section{RESEARCH METHOD}

The research strategy adopted is qualitative method and literature review of initial appraisal of seven construction case studies. The qualitative data were used to gather firsthand information about the research themes and the case studies were used to support and validate the qualitative findings. The data collection tools for the study include semistructured interview with experienced professionals. The study interview questions were designed based on existing literature. Pilot studies were conducted to ensure that the data collection tools were designed correctly. Ethical approval was sought from Coventry University Research Ethics Committee and it was granted. Data collected for the study were obtained from difference locations in England and Scotland. The main interview data collection instruments were designed to answer the study research objective. Stratified random sampling was used to select the study participants for the qualitative data. Study participants were contacted for interviews through emails, telephone contact, site visits and through The Chartered Institute of Building (CIOB) and Royal Institution of Chartered Surveyors (RICS) professional networking. All interviews were conducted face-to-face, telephone and responses to e-mails. 
The study population sample consist of construction clients, commercial managers, contract managers, commercial lawyers, quantity surveyors, managing directors of construction firms and business development managers. For validity, the study data collection was conducted on one-to-one basis. This method allowed the researchers to probe participants regarding the study aim. On the other hand, the study participants had opportunity to ask questions that were not clear.

\subsection{Interviews' data analysis}

Validity of the study qualitative data was upheld in three main areas: selection of participant profile, design of interview questions, and processing/presentation of interview data. Overall, a total of 13 semi-structured interviews were conducted with clients, industry practitioners and construction contractors. The study targeted interviewees with seasoned construction experience. All interviews were recorded using a digital recorder and personal information linked to study participants was removed because of data protection.

Textual excerpts of the interview data were transcribed into manuscript and inputted into Nvivo 12 software. Codes were assigned to key themes to facilitate filtering and sorting of data. The themes from the study aim were used to create codes and sub-codes from the transcribed data. Content analysis was used to analyze interview data for easy inferences to antecedents of discussions and certain words, themes or concepts spoken between interviewees and interviewer. Excerpts from interviews below were obtained using content analysis; by counting number of processes, extracting systematic and objective meaning from each content via making valid inferences from verbal and archive data. For example, when interviewees were asked to express their view concerning preventive approach to unsubstantiated claims in the UK construction industry; host of issues were raised about the subject matter. Subsequently, key contents were trimmed for better understanding and spontaneity of interaction between the researcher and study participants. Some textual excerpts are expressed verbatim; as illustrated below for conformability and better understanding of participants' views.

"... the culture in construction industry is undeniably the root causes of unsubstantiated claims... these problems exist because of dodgy contractors;... some project administrators maybe exploiting unsubstantiated claims to hold back money from contractors" - (Senior Commercial manager in a Large Construction company, London - the UK)

“.... unsubstantiated claims in construction are mainly caused by poor communication, lack of evidence, poor documentation, lack of systematic digital data capturing, ... Perhaps, the problem can only be cured by having rigorous review and check processes before claims are put forward" - (Managing Director, Medium construction company, Manchester UK)

"... Current claim process in the construction sector are faulty; with little check and balances; as a contractor if you submit a claim and the client project manager is not happy with it; he/she will simply put up flimsy excuses and throw it out; the industry 
need Systematic and Technical Appraisal mechanism to evaluate entire process of claim management...." - (Construction Manager, Large Construction Company Milton Keynes - the UK)

Interview data presented above suggest that unsubstantiated claim is a contemporary and genuine problem in the construction industry. However, most participants have mix perception about the research topic; the consensus on the issues is that both claimants and claim administrators usually do not handle unsubstantiated claims in good faith. However, interviewees were asked to expound on how prevent unsubstantiated claims and disputes in the construction industry. Some recorded extracts are expressed verbatim; as illustrated below:

"... in our previous projects we used lot of technologies ... yet we still had problems of unsubstantiated claims, ... to overcome this problem there must be a system or mechanism that will encourage early filing of claims, good claim data base, proper documentation, robust claim identification mechanisms, use of emerging technologies, etc ... the industry need to enhance its entire claim management processes" (Senior Commercial Manager, Railway infrastructure Project, the UK)

“... I am optimistic that balance communication between claimants and claim examiner and automation of claim management processes will help minimize unsubstantiated claim issues" - (Commercial lawyer - London).

"... I can confidently tell you most clients representative - project managers often view claims as dubious exercise that help contractors to make more money in a project; .. ... notwithstanding whether the claim was approved by them ... in an atmosphere of such mistrust pay master is most likely to view contractors' claims as unsubstantiated ..." - (Construction Cost Consultant - London)

To validate the findings from the qualitative inquiry; total of seven selected construction case studies relating to the UK construction industry were sought for better understanding of the problem as illustrated in table 3 below. The seven cases involve: construction projects, specialist contractors, and notable construction clients doing business in the UK. For robust analysis the case studies were drawn cases that were brought formally to competent court of jurisdiction and with clear verdicts. The following criteria were used to select construction cases in table 3: (i) the case relates to the UK construction industry, (ii) clear court verdict on the issue brought before the court, (iii) claim was identified as a major issue of dispute, (iv) judgement was not appealed. The key reason for selecting these seven cases is that there are valuable lessons concerning unsubstantiated claims and nature of construction disputes to be learnt from them.

These measures were taken to enable the researcher gather key lessons about the unsubstantiated claims and how to prevent the issue in the future. Table 3 presents seven case studies regarding nature of construction claims, disputes and key lessons learnt from each case study. 
Table 3: Selected construction case laws regarding claims and disputes

\begin{tabular}{|c|c|c|c|c|}
\hline $\begin{array}{l}\text { S. / } \\
\text { No. }\end{array}$ & Case Study & Year & $\begin{array}{l}\text { Nature of construction } \\
\text { claims }\end{array}$ & Key lesson learnt \\
\hline 1. & $\begin{array}{l}\text { Costain limited vs Tarmac } \\
\text { holdings } 2017\end{array}$ & 2017 & Defect and cost related & $\begin{array}{l}\text { Adequate and } \\
\text { timely communi- } \\
\text { cation }\end{array}$ \\
\hline 2. & $\begin{array}{l}\text { Atkins vs Secre- } \\
\text { tary of State for Transport }\end{array}$ & 2013 & Defect and cost related & $\begin{array}{l}\text { Clarification of } \\
\text { lump sum contract }\end{array}$ \\
\hline 3. & $\begin{array}{l}\text { Multiplex Constructions } \\
\text { (UK) Ltd vs Cleveland } \\
\text { Bridge UK Ltd }\end{array}$ & 2007 & Design and cost & $\begin{array}{l}\text { Undue influence } \\
\text { of lawyer and } \\
\text { adherence to use of } \\
\text { ADR }\end{array}$ \\
\hline 4. & $\begin{array}{l}\text { City Inn vs Shepherd Con- } \\
\text { struction }\end{array}$ & 2002 & Concurrent delays & $\begin{array}{l}\text { Lack of clarity re- } \\
\text { garding contractual } \\
\text { provision }\end{array}$ \\
\hline 5. & $\begin{array}{l}\text { Mears Ltd vs Costplan Ser- } \\
\text { vices (South East) Ltd } \\
\end{array}$ & 2019 & Practical completion & Failing to meet PC \\
\hline 6. & $\begin{array}{l}\text { Triple Point Technology Inc } \\
\text { vs PTT Public Company } \\
\text { Ltd }\end{array}$ & 2019 & $\begin{array}{l}\text { Liquidated damages } \\
\text { following termination of } \\
\text { the contract }\end{array}$ & Time management \\
\hline 7. & S\&T (UK) Ltd vs Grove & 2018 & $\begin{array}{l}\text { Payment regimes and } \\
\text { "smash and grab adjudi- } \\
\text { cations" }\end{array}$ & $\begin{array}{l}\text { Payment require- } \\
\text { ment }\end{array}$ \\
\hline
\end{tabular}

\section{DISCUSSION AND FINDINGS}

Findings from table 3 show that unanimity with the study literature regarding unsubstantiated claims, effectiveness of claim and key lessons learnt from various case studies. Most professionals in the industry believe that balance communication between claimants and claim examiner, early filing of claims, good claim data base, proper documentation, robust claim identification mechanisms, use of emerging technologies are required factors needed to enhance unsubstantiated claims that are often too familiar in the construction industry. Perhaps, unsubstantiated claims issues in construction can be best managed using tactical approach such as timely notification of claims supported by unquestionable evidence. The study identified that over $38 \%$ of claims submitted by construction contractors are usually rejected due to lack of verified and corroborated evidence. Findings from the seven case studies reviewed show that time (delay) and variation related claim constitute approximately $52 \%$ of most construction claim. Defects and weather related claims consist of approximately $38 \%$ of claim. While, design and change order from clients entails approximately $6 \%$ of claim and other factors consist of remaining $4 \%$ of claims. The study also identified that most construction projects have weak documentation processes; in terms of modern data storage and processing.

\section{CONCLUSION}

Initial findings reveal that claim management processes in the construction sector 
are far-off from perfection. Unsubstantiated claims remain a leading cause of disputes in the construction industry. To prevent unsubstantiated claims there is need for robust systematic and technical claim appraisal (STA) process. The proposed claim appraisal process should entail details record keeping of 4Ms i.e. costs of Materials, Machine, Manpower, and Money. In addition, to update transaction register, training of competent staff to ensure in-depth review of claims, precise and transparent weather recording, information of construction programme. Finally, thorough understanding of relevant compensation events and robust claim management processes (.i.e. identification, notification, examination, documentation, presentation and analysis and timely resolution of claims through negotiation) are vital ingredient to help contracting parties substantiate construction claims. Though, most UK construction projects already use close circuits television (CCTV) cameras/system to monitor production and security properties on site; the same system can be modified to help to corroborate claims.

\section{REFERENCES}

ARCADIS (2018). Global Construction Disputes Report. ARCADIS.

Bonaventura, H. W. H. (2015). Construction Claim Types and causes for a Large-Scale Hydropower Project in Bhutan 20, 49-63.

Barrie, D. S. \& Paulson, B. C. (1992). Professional construction management: including CM, design-construct, and general contracting. McGraw-Hill Science/Engineering/Math.

Chappell, D. (2014). The JCT Standard Building Contract 2011: An explanation and guide for busy practitioners and students. John Wiley \& Sons.

Hameed Memon, A., Abdul Rahman, I. \& Faris Abul Hasan, M. (2014). Significant Causes and Effects of Variation Orders in Construction Projects. Research Journal of Applied Sciences, Engineering and Technology, 7(21), 4494-4502.

Jack, P., Russell, C. \& Bert, B. (2001). Validation of trace-driven simulation models: bootstrap tests. Management Science, 47(11), pp.1533-1538.

Jergeas, G. F. \& Hartman, F. T. (1994). Contractors' construction-claims avoidance. Journal of Construction Engineering and Management, 120(3), pp.553-560.

James G. Zack, J. (2013). Delivering Disputes Free Construction Projects: Part-I-Planning, Design \& Bidding.

Retrieved from Navigant Construction Forum. Available at: https://conimas.com/pdf/ DELIVERING\%20

DISPUTE\%20FREE\%20PROJECTS\%20-\%20PART\%20I\%20-\%20NCF\%20FINAL.pdf [Accessed 25 Nov. 2019].

Kumaraswamy, M. (2003). Conflicts, Claims and Disputes in Construction. vol. 4.

London Court of International Arbitration (2018). Construction Claims Guide.

Long, R. J. (2017). Analysis of Concurrent Delay on Construction Claims - 201746.

Levin, P. (1998), May. Construction contract claims, changes \& dispute resolution. American Society of Civil Engineers.

Sun, M. \& Meng, X. (2009). Taxonomy for change causes and effects in construction projects. International journal of project management, 27(6), pp. 560-572. 
Tochaiwat, K. \& Chovichien, V. (2004) Claim Management Process.

Uher, T. E. (1994). What is Partnering. Australian Construction Law Newsletter, 34, pp. 49-61.

Vidogah, W. \& Ndekugri, I. (1998) Improving the Management of Claims on Construction Contracts: Consultant's Perspective. Construction Management and Economics, 16 (3), 363 372.

World Bank, (2012). The World Bank Annual Report 2012. The World Bank.

Wong, Y. L. (2005). Factors affecting the choice of dispute resolution methods. (Unpublished bachelors dissertation). National University of Singapore.

Yates, F. (2003). The occult philosophy in the Elizabethan age. Routledge. 